\title{
HUBUNGAN ANTARA PENGETAHUAN TENTANG KESEHATAN REPRODUKSI DENGAN PERNIKAHAN DINI DI KECAMATAN SELAJAMBE KABUPATEN KUNINGAN PERIODE 2018 - 2019
}

\author{
Dea Setia Dwi Rusmilial ${ }^{1}$ Entin Jubaedah ${ }^{2}$, Suratmi ${ }^{3}$ \\ Poltekkes Kemenkes Tasikmalaya ${ }^{123}$ \\ e-mail: ${ }^{1}$ deasetiaan10@gmail.com, ${ }^{2}$ entinjubaedah1712@gmail.com, ${ }^{3}$ ratmiza@yahoo.co.id
}

\begin{abstract}
Background : Early marriage according to Law number 16 of 2019 paragraph 7 mentioned marriage is allowed if men and women reach the age of 19 years. In Kuningan Regency, there is an increase in the early marriage incidence in 2016 to 2019. Cases of early marriage based on data in Religious Affair Office of Selajambe subdistrict as much as $18 \%$ including the high category of all marriages that occurred entered into early marriage in 2019. There is a match between the data obtained from Selajambe Primary Health Facility and Religious Affair Office of Selajambe subdistrict, i.e. the level of young marriage with the number of pregnancies in women aged $\leq$ 20 years. This study aims to find out the relationship between reproductive health knowledge and the rate of early marriage in Selajambe Subdistrict Kuningan Year 2020.

Method: This research used quantitative analytical research with correlation research design, and cross sectional approach method. Research population is newly married women in 2018 to 2019 period, using purposive sampling techniques. Research sample of 30 respondents. Instruments used are questionnaires. Analysis of data used univariate and bivariate with Chi-Square test $\left(X^{2}\right)$ with $(\alpha) 0.05$ degree of meaning.

Research results : Most respondents aged > 20 years as many as 12 people (40\%), and educated elementary / junior high school as many as 23 people (76.7\%). Most married respondents have sufficient knowledge of reproductive health. The result of statistical analysis of Chi square obtained a value of p value 0.042 smaller than (a) 0.05 .

Conclusion: There is a relationship between knowledge about reproductive health and the level of early marriage in Selajambe Subdistrict, Kuningan District in 2020.
\end{abstract}

Keywords : Reproductive Health Knowledge, Early marriage

\begin{abstract}
ABSTRAK
Latar Belakang : Pernikahan dini menurut UU nomor 16 tahun 2019 ayat 7 disebutkan perkawinan diizinkan jika laki-laki dan perempuan mencapai umur 19 tahun. Di Kabupaten Kuningan kejadian pernikahan dini pada Tahun 2016 sampai Tahun 2019 terjadi peningkatan. Kasus pernikahan dini berdasarkan data di KUA Kecamatan Selajambe sebanyak 18\% termasuk kategori tinggi dari seluruh pernikahan yang terjadi masuk dalam pernikahan dini pada tahun 2019. Data yang diperoleh dari Puskesmas Selajambe dan KUA Kecamatan Selajambe terdapat kecocokan jumlah data, yaitu tingkat pernikahan muda dengan jumlah kehamilan pada perempuan yang berumur $\leq 20$ tahun. Metode Penelitian : Merupakan penelitian analitik kuantitatif dengan desain penelitian korelasi dengan metode pendekatan Cross Sectional. Populasi penelitian adalah perempuan yang baru menikah periode tahun 2018 s.d 2019, menggunakan teknik purposive sampling. Sampel penelitian sebanyak 30 responden. Instrumen yang digunakan adalah kuesioner. Analisis data yang digunakan univariat dan bivariat dengan uji $C h i-$ Square $\left(\mathrm{X}^{2}\right)$ dengan derajat kemaknaan $(\alpha) 0,05$.

Hasil penelitian : Sebagian besar responden berusia > 20 tahun sebanyak 12 orang (40\%), dan berpendidikan SD/SMP sebanyak 23 orang $(76,7 \%)$. Sebagian besar responden yang telah menikah memiliki pengetahuan yang cukup tentang kesehatan reproduksi. Hasil analisis statistik Chi square didapatkan nilai $p$ value 0,042 lebih kecil dari $(\alpha) 0,05$.

Kesimpulan : Terdapat hubungan antara pengetahuan tentang kesehatan reproduksi dengan pernikahan dini di Kecamatan Selajambe Kabupaten Kuningan Periode 2018 - 2019.
\end{abstract}

Kata Kunci : Pengetahuan Kesehatan Reproduksi, Pernikahan dini 


\section{PENDAHULUAN}

\section{Latar Belakang}

Pernikahan dini di Indonesia masih sangat tinggi, menduduki peringkat ke 7 di dunia, sehingga banyak sekali dampak kepada anak. Menurut UU nomor 16 tahun 2019 pasal 7 disebutkan bahwa perkawinan hanya diizinkan apabila pria dan wanita sudah mencapai umur 19 (sembilan belas) tahun. Tetapi menurut Badan Pusat Statistik (2018) terdapat $37,91 \%$ anak perempuan di Indonesia yang berumur 10-17 tahun yang berstatus kawin dan cerai menikah di umur 16 tahun. Di Indonesia Tahun 2018 tingkat tertinggi terjadinya pernikahan dini yaitu provinsi Kalimantan Selatan sebanyak 22,77\% diikuti oleh Jawa Barat sebanyak 20,93\%, Jawa Timur 20,73\%.(Badan Pusat Statistik,2018).

Perempuan merupakan salah satu sasaran dalam membangun kesehatan karena dari ibu yang baik menghasilkan generasi yang sehat. Kesehatan reproduksi pada perempuan melibatkan mental dan fisik. Perkembangan zaman mempengaruhi perilaku perempuan. Perilaku buruk perempuan yang berkembang seperti merokok, minum obat - obatan, minum - minuman keras, dan pergaulan bebas yang menyebabkan risiko tinggi penyakit menular seksual dan kehamilan yang tidak diinginkan.(Lala, 2015)

Dari penelitian yang dilakukan Windiarto dan Yanto Tahun 2018 dampak buruk yang akan dihadapi bagi anak-anak perempuan yang pernah menikah atau bercerai muda adalah hilangnya kesempatan melanjutkan pendidikan. Mereka tidak mau melanjutkan sekolahnya karena berbagai sebab antara lain karena tanggung jawab merawat anak atau malu karena status pernikahannya.

\section{Tujuan Penelitian}

Tujuan Penelitian yang dilakukan secara umum untuk mengetahu hubungan antara pengetahuan tentang kesehatan reproduksi dengan pernikahan dini di Kecamatan Selajambe Kabupaten Kuningan Periode 2018 - 2019. Secara khusus untuk mengetahui karaktersistik umur menikah dan pendidikan, mengetahui pengetahuan tentang kesehatan reproduksi, mengetahui pernikahan dini, dan menganalisis hubungan antara pengetahuan tentang kesehatan reproduksi dengan pernikahan dini di Kecamatan Selajambe Kabupaten Kuningan Periode $2018-2019$

\section{Hipotesis}

Dari latar belakang yang ada telah di dapatkan bahwa terdapat hubungan antara pengetahuan tentang kesehatan reproduksi dengan pernikahan dini di Kecamatan Selajambe Kabupaten Kuningan Periode 2018 - 2019

\section{METODE}

Penelitian ini menggunakan studi analitik kuantitatif denga metode pendekatan Cross Sectional. Teknik pengambilan data menggunakan Purposive Sampling yang melibatkan 30 responden. Teknik analisis data menggunakan Analisis Univariat dan Bivariat. Pengumpulan data dengan menggunakan Kuesioner pilihan ganda.

\section{HASIL}

1. Distribusi Frekuensi Responden Berdasarkan Umur Menikah Di Kecamatan Selajambe Kabupaten Kuningan Periode 2018 - 2019

Tabel 1

Distribusi Frekuensi Responden Berdasarkan Umur Menikah Di Kecamatan Selajambe Kabupaten Kuningan Periode 2018 - 2019

\begin{tabular}{ccc}
\hline $\begin{array}{c}\text { Umur } \\
\text { Menikah }\end{array}$ & $\mathrm{n}$ & Persentase (\%) \\
\hline 20 Tahun & 25 & 83,3 \\
$\geq 20$ Tahun & 5 & 16,7 \\
\hline Jumlah & 30 & 100 \\
\hline
\end{tabular}

Pada tabel 1, dapat diketahui bahwa sebagian besar responden berumur $\leq 20$ tahun sebanyak 25 orang $(83,3 \%)$

2. Distribusi Frekuensi Responden Berdasarkan Pendidikan di Kecamatan Selajambe Kabupaten Kuningan Periode 2018 - 2019

Tabel 2

Distribusi Frekuensi Responden Berdasarkan Pendidikan di Kecamatan Selajambe Kabupaten Kuningan

Periode 2018 - 2019

\begin{tabular}{lcc}
\hline \multicolumn{1}{c}{ Pendidikan } & $\mathrm{n}$ & Persentase (\%) \\
\hline SD/SMP & 23 & 76,7 \\
SMA & 5 & 16,7 \\
Perguruan Tinggi & 2 & 6,6 \\
\hline \multicolumn{1}{c}{ Jumlah } & 30 & 100
\end{tabular}

Dari tabel 2 dapat diketahui bahwa sebagian besar responden berpendidikan SD/SMP sebanyak 23 orang $(76,7 \%)$ 
3. Distribusi Frekuensi Responden Berdasarkan Pengetahuan Tentang Kesehatan Reproduksi Di Kecamatan Selajambe Kabupaten Kuningan Periode 2018 - 2019

Tabel 3

Distribusi Frekuensi Responden Berdasarkan Pengetahuan Tentang Kesehatan Reproduksi

Di Kecamatan Selajambe Kabupaten Kuningan Periode 2018 -2019

\begin{tabular}{lcc}
\hline Pengetahuan & $\mathrm{n}$ & Persentase (\%) \\
\hline Baik & 7 & 23,3 \\
Cukup & 17 & 56,7 \\
Kurang & 6 & 20 \\
\hline Jumlah & 30 & 100 \\
\hline
\end{tabular}

Dari tabel 3 dapat diketahui bahwa sebagian besar responden memiliki pengetahuan cukup sebanyak 17 orang $(56,7 \%)$

4. Hubungan Antara Pengetahuan Tentang Kesehatan Reproduksi Dengan Pernikahan Dini Di Kecamatan Selajambe Kabupaten Kuningan Periode 2018 - 2019

Tabel 4

Hubungan Antara Pengetahuan Tentang Kesehatan Reproduksi Dengan Pernikahan Dini Di Kecamatan Selajambe

Kabupaten Kuningan

Periode 2018 - 2019

\begin{tabular}{|c|c|c|c|c|c|}
\hline \multirow{2}{*}{ Pengetahuan } & \multicolumn{4}{|c|}{ Umur Menikah } & \multirow{2}{*}{ Total } \\
\hline & $\mathrm{Ya}$ & $\begin{array}{c}\text { Persentase } \\
(\%)\end{array}$ & Tidak & $\begin{array}{c}\text { Persentase } \\
(\%)\end{array}$ & \\
\hline Kurang & 6 & 20 & 0 & 0 & 6 \\
\hline Cukup & 11 & 36,7 & 6 & 20 & 17 \\
\hline Baik & 2 & 6,7 & 5 & 16,7 & 7 \\
\hline Jumlah & 19 & 63,3 & 11 & 36,7 & 30 \\
\hline
\end{tabular}

Analisis data dengan yang menggunakan uji

Chi Square diperoleh nilai sebesar 0,042. Bila dibandingkan dengan $p$ value ( 0,042 lebih kecil dari 0,05). Dengan demikian Ha diterima, sehingga dapat disimpulkan bahwa ada hubungan antara pengetahuan tentang kesehatan reproduksi dengan pernikahan dini di Kecamatan Selajambe

Kabupaten Kuningan Periode 2018 - 2019

\section{PEMBAHASAN}

\section{Analisi Univariat}

\section{a. Umur Menikah}

Berdasarkan tabel 1, dapat diketahui bahwa sebagian besar responden berumur $\leq$ 20 tahun sebanyak 25 orang ( 83,3\%). Problem kesehatan reproduksi yang dialami para perempuan dan remaja biasanya dikarenakan banyak faktor. Faktor penyebab munculnya problem reproduksi terdiri dari faktor yang bersifat internal maupun eksternal. Faktor yang bersifat internal terkait dengan persoalan pemahaman mengenai kesehatan reproduksi. Faktor yang bersifat eksternal biasanya merupakan faktor yang berhubungan dengan hal yang berada di luar kemampuan diri individu seperti lingkungan, pergaulan, perkembangan teknologi informasi dan komunikasi, dan lain-lain. Faktor pemahaman mengenai kesehatan reproduksi menyumbangkan kontribusi yang begitu besar terkait dengan persoalan-persoalan reproduksi remaja (Hasanah, 2017).

Orang dengan pemahaman tentu mengarahkan dirinya untuk tidak melakukan faktor yang menyebabkan risiko dan dampak negatif bagi diri sendiri. Sebaliknya, remaja yang memiliki pemahaman rendah, cenderung kurang mremiliki kepedulian, kesadaran dalam menjaga dan memelihara organ $P$ reproduksinya, yang selanjutnya sering Valukerakhir pada terjadinya kekerasan seksual pada remaja. Data yang dilansir oleh beberapa media online menyebutkan bahwa masih banyak remaja yang belum memahami kesehatan reproduksi, bagaimanakah fungsi organ reproduksi, bagaimana proses terjadinya reproduksi. Kecenderungan ini menyebabkan banyak remaja yang mengalami kekerasan seksual dan menjadi korban perilaku seks bebas (Hasanah, 2017).

Dari hasil penelitian tersebut, peneliti berpendapat bahwa ada beberapa faktor yang menyebabkan terjadinya umur pernikahan dini diantaranya tradisi lokal 
(budaya turun temurun melakukan pernikahan dini karena ditakutkan orang tua yang sudah lansia ingin segera menimang cucu dan dimasyarakat yang memegang teguh agama atau keyakinan agama yang kuat sangat diperlukan menyegerakan pernikahan karena ditakutkan terjadi fitnah), atau disebabkan karena faktor ekonomi keluarga dan kemungkinan lainnya.

\section{b. Pendidikan Responden}

Berdasarkan hasil penelitian pada tabel 2, dapat diketahui bahwa sebagian besar responden berpendidikan dasar sebanyak 23 orang $(76,7 \%)$. Hal ini sesuai dengan penjelasan tentang peran pendidikan anakanak sangat mempunyai peran yang besar. Jika seorang anak putus sekolah pada umur wajib sekolah, kemudian mengisi waktu dengan bekerja. Saat ini anak tersebut sudah merasa cukup mandiri, sehingga merasa mampu untuk menghidupi diri sendiri (Baitul Alim. 2017)

Pendidikan adalah usaha sadar dan terencana untuk mewujudkan suasana belajar dan proses pembelajaran agar masyarakat secara aktif mengembangkan potensi dirinya untuk memiliki kekuatan spiritual keagamaan, pengendalian diri, kepribadian, kecerdasan, akhlak mulia, serta keterampilan yang diperlukan dirinya dan masyarakat. Pendidikan yang dijalani seseorang memiliki pengaruh pada peningkatan kemampuan berpikir, dengan kata lain seseorang yang berpendidikan lebih tinggi akan dapat mengambil keputusan yang lebih rasional, umumnya terbuka untuk menerima perubahan atau hal baru dibandingkan dengan individu yang berpendidikan lebih rendah (Kemenkes RI, 2015).

Peneliti berpendapat, dalam penelitian ini walaupun responden berpendidikan dasar tetapi memiliki pengetahuan yang cukup tentang kesehatan reproduksi hal ini dimungkinkan karena di era digital ini masyarakat sangat mudah untuk dapat mengakses informasi mengenai apapun. Jadi walaupun berpendidikan dasar mereka dapat menerima berbagai informasi atau pengetahuan melalui media elektronik yang sudah dapat menjangkau ke seluruh pelosok pedesaan.

\section{c. Pengetahuan Responden}

Berdasarkan hasil penelitian pada tabel 3, dapat diketahui bahwa sebagian besar responden memiliki pengetahuan cukup sebanyak 17 orang $(56,7 \%)$.
Menurut Notoatmodjo, (2015) bahwa pengetahuan adalah hasil "tahu", dan ini terjadi setelah orang melakukan pengindraan terhadap suatu objek tertentu. Penginderaan terjadi melalui panca indra manusia yakni: indra penglihatan, pendengaran, penciuman, rasa, dan raba. Sebagian besar pengetahuan manusia diperoleh melalui mata dan telinga.

Tujuan pendidikan ini mempunyai sifat yang abstrak, karena memuat nilainilai yang sifat abstrak, sifat umum, ideal, dan kandungannya sangat luas, hal ini menyebabkan sulitnya dilaksanakan dalam kegiatan praktek. Pendidikan harus berupa tindakan yang ditujukan kepada masyarakat dalam kondisi tertentu, tempat tertentu dan waktu tertentu, dengan menggunakan alat tertentu. Pelaksanaannya hanya mungkin apabila tujuan yang ingin dicapai itu dibuat secara jelas, konkret, dan lingkup kandungannya terbatas. Jadi, tujuan-tujuan umum ini perlu dirinci sehingga menjadi tujuan yang lebih khusus dan terbatas, sehingga memudahkan untuk direalisasikan dalam praktek.

Pengetahuan adalah hasil penginderaan manusia atau hasil yang diperoleh seseorang terhadap suatu objek melalui panca indera yang dimiliki. Dengan berjalannya waktu penginderaan akan menghasilkan pengetahuan yang sangat dipengaruhi oleh intensitas perhatian dan sudut pandang terhadap suatu objek. Pengetahuan seseorang diperoleh melalui panca indera seperti penglihatan (mata) dan pendengaran (telinga). Dalam Penelitian ini kuesioner hanya sampai 2 tingkatan yaitu tahu (know) dan memahami (comprehension).

Peneliti berpendapat bahwa pengetahuan tentang kesehatan reproduksi yang telah dimiliki responden sudah cukup baik hal ini dimungkinkan bahwa responden sudah mendapatkan informasi yang didapat baik dari orang tua, media informasi baik secara elektronik maupun nonelektronik berupa leaflet, brosur, spanduk, poster atau informasi secara langsung dari tenaga kesehatan.

\section{Analisis Bivariat}

Berdasarkan tabel 4, hasil penelitian diketahui bahwa dari 30 responden terdiri dari 6 orang dengan pengetahuan kurang, pengetahuan cukup 17 orang dan pengetahuan baik 7 orang. Dari sebanyak 6 responden yang berpengetahuan kurang, sebagian besar menikah di usia dini sebanyak 6 orang (100\%). Dari sebanyak 17 responden yang berpengetahuan cukup, sebagian besar menikah di usia dini sebanyak 11 orang 
$(36,7 \%)$. Dari sebanyak 7 responden yang berpengetahuan baik, sebagian besar tidak menikah di umur dini sebanyak 5 orang $(16,7 \%)$.

Hasil analisis statistik Chi square dari variabel penelitian hubungan antara pengetahuan tentang kesehatan reproduksi dan pernikahan dini mendapatkan nilai $p$ value 0,042 lebih kecil dari $\alpha$ 0,05. Dengan demikian Ha diterima yang artinya ada hubungan antara pengetahuan tentang kesehatan reproduksi dengan pernikahan dini di Kecamatan Selajambe Kabupaten Kuningan Periode 2018 - 2019.

Hal ini sesuai dengan penelitian yang dilakukan oleh Agtikasari Tahun 2017 yang menyatakan pada penelitiannya bahwa siswa yang memiliki tingkat pengetahuan tentang kesehatan reproduksi yang baik akan menolak melakukan pernikahan dini, yang mendapatkan hasil bahwa siswa yang kategori pengetahuan baik memiliki jumlah tertinggi yaitu sebanyak 95 orang atau $(74,8 \%)$, dan jumlah terendah pada kategori pengetahuan kurang yaitu sebanyak 10 orang atau $(10,2 \%)$ sehingga sikap mendukung terhadap pernikahan usia dini yaitu sebanyak 56 orang atau $(44,1 \%)$ sedangkan yang memiliki sikap tidak mendukung terhadap pernikahan usia dini yaitu sebanyak 71 orang atau $(55,9 \%)$.

Penelitian lain yang sejalan dengan penelitian ini, yaitu penelitian yang dilakukan Lestari (2015) tentang "Gambaran faktor-faktor penyebab pernikahan usia dini pada remaja di Kecamatan Cimahi Kabupaten Kuningan Tahun 2015" dimana hasilnya yaitu Gambaran pernikahan usia dini pada remaja berdasarkan faktor pendidikan adalah sebagian besar remaja berpendidikan dasar sebanyak 70 responden (80,5\%), dan sebagian kecil remaja berpendidikan menengah sebanyak 17 responden $(19,5 \%)$. Hasil uji statistik menunjukkan ada hubungan tingkat pengetahuan dan terjadinya pernikahan dini.

Program kesehatan reproduksi remaja mulai menjadi perhatian karena beberapa alasan yaitu ancaman HIV/AIDS menyebabkan perilaku seksual dan kesehatan reproduksi remaja, kejadian IMS yang tertinggi pada remaja khususnya perempuan, jumlah kelahiran pada remaja dibawah umur 20 tahun pun meningkat karena kurangnya pendidikan seksual atau kesehatan reproduksi serta pelayanan yang dibutuhkan remaja, pengetahuan dan praktik pada tahap remaja akan menjadi dasar perilaku yang sehat pada tahap selanjutnya dalam kehidupan remaja sehingga investasi pada program kesehatan reproduksi remaja akan bermanfaat selama hidupnya (Lala, 2015).

Kasus kehamilan diluar nikah, pernikahan dini, HIV/AIDS di pedesaan dan masalah kesehatan remaja (anemia, stunting, kekurangan energi kronik dan kegemukan). Hal ini yang menjadi permasalahan karena, kurangnya pengetahuan remaja tentang kesehatan reproduksinya, identifikasi masalah kesehatan baru ditemukan pada saat remaja tersebut akan menjadi calon ibu atau ayah, karena kurangnya deteksi dini pada umur remaja (Pratiwi, Hamdiyah dan Asnuddin, 2020).

Penelitian ini, sesuai dengan hasil penelitian yang dilakukan oleh Ulfah (2018) bahwa ada hubungan antara tingkat pengetahuan remaja tentang pernikahan dini dengan kejadian pernikahan dini di Kecamatan Saptosari Kabupaten Gunungkidul. Berdasarkan hasil penelitian, responden yang banyak melakukan pernikahan dini adalah responden yang memiliki pengetahuan kurang tentang pernikahan dini. Dari variabel penelitian tingkat pengetahuan dan kejadian pernikahan dini didapatkan hasil ada hubungan yang bermakna antara tingkat pengetahuan responden tentang pernikahan dini dengan kejadian pernikahan dini dengan nilai $p$ value $=0,000$. Penelitian ini telah dilakukan pada bulan Desember 2017 di Desa Jetis, Saptosari, Gunungkidul diperoleh responden remaja usia 16-19 tahun yang berjumlah 110 orang. Warga tersebut dijadikan sebagai subyek penelitian untuk mengetahui hubungan tingkat pengetahuan remaja tentang pernikahan dini dengan kejadian pernikahan dini.

Selain itu, penelitian ini juga selaras dengan hasil penelitian Fitriah Mutmainah (2017). Fitriah melakukan penelitian ini menggunakan survey analitik dengan pendekatan cross sectional. Populasi penelitiannya adalah siswa-siswi remaja kelas X dan XI di SMA Negeri 1 Gamping Sleman. Sampel sebanyak 100 siswa-siswi remaja dengan teknik sampling quota. Hasil uji analisis statistika dengan uji korelasi Kendall Tau didapatkan hasil nilai significant p-value sebesar , $000(\leq 0,05)$ sehingga dapat disimpulkan bahwa terdapat hubungan yang bermakna antara pengetahuan dengan sikap remaja terhadap Pernikahan Dini di SMA Negeri 1 Gamping Sleman dengan nilai Correlation Coefficient 0,426 yang bermakna sedang. Dengan demikian ada hubungan signifikan antara pengetahuan dengan sikap remaja terhadap pernikahan dini. Hasil penelitian untuk Sekolah dapat bekerjasama dengan dinas sosial dan petugas kesehatan di Puskesmas Gamping Sleman memberikan penyuluhan materi tentang kesehatan reproduksi remaja termasuk materi tentang pernikahan dini.

Penelitian lain yang hampir serupa adalah penelitian yang dilakukan oleh Ade Lucky Yani dkk (2017). Berdasarkan penelitiannya dapat disimpulkan bahwa sebagian besar remaja yang melakukan pernikahan dini di Desa Sidamulya Kecamatan Astanajapura Kabupaten Cirebon Periode Januari s/d Mei 2017 merupakan remaja 
akhir yang berusia 16-21 tahun yaitu sebanyak 14 orang atau $73,7 \%$. Adapun jenis penelitiannya termasuk penelitian kuantitatif. Analisis data meliputi analisis univariat dan analisis bivariat dengan Uji Korelasi Spearman karena data berdistribusi tidak normal. Tingkat pengetahuan remaja putri tentang pernikahan dini di Desa Sidamulya Kecamatan Astanajapura Kabupaten Cirebon dalam kategori cukup sebanyak 9 orang $(47,4 \%)$. Terdapat hubungan antara karakteristik remaja putri (umur) dengan pengetahuan tentang pernikahan dini $(r=0,578$ dan $\rho=0,010)$ di Desa Sidamulya Kecamatan Astanajapura Kabupaten Cirebon periode Januari s.d Mei 2017.

Menurut Ade Lucky (2017) menyarankan atas hasil penelitiannya kepada remaja putri yang akan melakukan pernikahan sebaiknya dipikirkan terlebih dahulu, karena umur dapat mempengaruhi pengetahuan seseorang, dan apabila pengetahuan sudah cukup baik akan tetapi secara psikologis, tingkat emosional pada remaja belum stabil.

Program Posyandu Remaja yang ada di Kecamatan Selajambe untuk beberapa Desa sering dilakukan setiap bulannya. Di lakukan penyuluhan mengenai kesehatan reproduksi di sekolah SD, SMP, dan SMA rutin setiap 6 bulan sekali yang sekarang terhambat akibat pandemi COVID-19.

Berdasarkan uraian analisis yang telah dipaparkan di atas peneliti berpendapat bahwa semakin baik pengetahuan tentang kesehatan reproduksi semakin besar kemungkinan tidak melakukan pernikahan dini dengan cara mengetahui tentang kesehatan reproduksi, memahami baik dan buruk tentang akibat melakukan pernikahan dini tersebut sehingga dari segi fisik, biologis, dan emosional sudah matang, agar dapat melahirkan generasi yang sehat dan kuat.

\section{KESIMPULAN}

Dari hasil penelitian dan pembahasan yang telah disampaikan maka peneliti dapat menyimpulkan sebagai berikut :

1. Sebagian besar responden berumur $\leq 20$ tahun dan sebagian besar berpendidikan SD/SMP.

2. Sebagian besar responden yang telah menikah memiliki pengetahuan yang cukup tentang kesehatan reproduksi.

3. Sebagian besar responden melakukan pernikahan dini.

4. Terdapat hubungan antara pengetahuan tentang kesehatan reproduksi dengan pernikahan dini di Kecamatan Selajambe Kabupaten Kuningan Periode 2018 - 2019.

\section{DAFTAR PUSTAKA}

1. Afriani, R. dan Mufdlilah (2016) "Analisis Dampak Pernikahan Dini Pada Remaja Putri di Desa Sidoluhur Kecamatan Godean Yogyakarta," Rakernas Aipkema, hal. 235-243. Tersedia pada: https://jurnal.unimus.ac.id/index.php/psn120120 10/article/view/2102.

2. Agtikasari, N. (2017) "HUBUNGAN PENGETAHUAN TENTANG PERNIKAHAN USIA DINI DENGAN SIKAP SISWA TERHADAP PERNIKAHAN USIA DINI DI SMA NEGERI 2 BANGUNTAPAN TAHUN 2015," Jurnal Ners dan Kebidanan (Journal of Ners and Midwifery), 4(1), hal. 051-055. doi: 10.26699/jnk.v4i1.art.p051-055.

3. Aisah, U. N., Th, E. M., \& Rahmawati, A. (2018). HUBUNGAN TINGKAT PENGETAHUAN REMAJA TENTANG PERNIKAHAN DINI DENGAN KEJADIAN PERNIKAHAN DINI DI KECAMATAN SAPTOSARI KABUPATEN GUNUNGKIDUL TAHUN 2017 (Doctoral dissertation, Poltekkes Kemenkes Yogyakarta).

4. Arikunto, S. (2019) . Prosedur penelitian.

5. Azzahy, G. S. (2008) "Faktor-Faktor yang Mempengaruhi Perilaku," 2008. Tersedia pada: http://syakira-blogspot.com/2008/11/faktorfaktor-yang-mempengaruhi.html.

6. Baitul Alim, 2017. Psilogozone. Jakarta : Elecomp.

7. Chandrawati, R. (2016) "Faktor Risiko yang Berpengaruh dengan Kejadian Kanker Serviks di RSUD dr. H. Abdul Moeloek Provinsi Lampung," Jurnal Kesehatan, 7(2), hal. 282. doi: 10.26630/jk.v7i2.202.

8. Depdikbud. 2016. Pengertian Istilah Kependudukan. Jakarta : Depdiknas

9. Dhamar Yudho Aji onesia, dan A. F. M. (2008) "FAKTOR RISIKO YANG BERHUBUNGAN DENGAN KEJADIAN PREEKLAMPSIA BERAT PADA IBU HAMIL DI RSUD RADEN MATTAHER JAMBI TAHUN 200," Cell, 151(4), hal. 1-46. doi: 10.1016/j.cell.2009.01.043.

10. Elisabeth. (2017) "Pernikahan Usia Remaja dan Problematika".

http://www.pakguruonline.pendidikan.net, diunduh tanggal 28 Juni 2020

11. Erna Setiawati, H. W. (2018) "HUBUNGAN PENGETAHUAN REMAJA TENTANG RESIKO PERNIKAHAN DINI DENGAN KEINGINAN MELAKUKAN PERNIKAHAN DINI DI SMK KANISIUS UNGARAN 
KABUPATEN SEMARANG," 2, hal. 47-53.

12. Hasanah, H. (2017) "PEMAHAMAN KESEHATAN REPRODUKSI BAGI PEREMPUAN: Sebuah Strategi Mencegah Berbagai Resiko Masalah Reproduksi Remaja," Sawwa: Jurnal Studi Gender, 11(2), hal. 229. doi: 10.21580/sa.v11i2.1456.

13. Hamid. (2018) "Kajian Psikologi Kesehatan Reproduksi Remaja” Jakarta : Antartika Press

14. Hurlock. (2001) "Perkembangan Remaja" Yogyakarta : Pustaka Ilmu

15. Indrasari, N. (2012) "Faktor Resiko Pada Kejadian Berat Badan Lahir Rendah (Bblr)," Jurnal Keperawatan, 8(2), hal. 114-123.

16. Karta Asmana, S., Syahredi, S. dan Hilbertina, N. (2016) "Hubungan Usia dan Paritas dengan Kejadian Preeklampsia Berat di Rumah Sakit Achmad Mochtar Bukittinggi Tahun 2012 2013," Jurnal Kesehatan Andalas, 5(3), hal. 640 646. doi: 10.25077/jka.v5i3.591.

17. Kemenkes RI. (2015) "Survei Dasar Kesehatan Indonesia" Jakarta : Kemenkes

18. Khotimah, Khusnul; Ratnaningsih, S. (2017) "Faktor-faktor yang Mempengaruhi Kejadian Bayi Baru Lahir dengan Berat Badan Lahir Rendah di RSUD wonosari," Bidan Pendidik Jenjang Diploma IV, hal. 6-10.

19. Koentjaraningrat. (2015) "Antropologi Kesehatan. Jakarta" : Media Press, Revisi

20. Lala, H. (2015) "Evaluasi Program Kesehatan Reproduksi Remaja 'DAKU!' (Dunia Remajaku Seru) di SMU,” JPS (Jurnal Pendidikan Sains), 3(2), hal. 90-97. doi: 10.17977/jps.v3i2.7657.

21. Lestari, E (2015), " Gambaran faktor-faktor penyebab pernikahan usia dini pada remaja di Kecamatan Cimahi Kabupaten Kuningan Tahun 2015", STIKKU

22. Yani, A. L., Mardiani, N., \& Rekhliana, E. L. (2017). HUBUNGAN KARAKTERISTIK REMAJA PUTRI DENGAN PENGETAHUAN TENTANG PERNIKAHAN DINI DI DESA SIDAMULYA KECAMATAN ASTANAJAPURA KABUPATEN CIREBON TAHUN 2017. JURNAL KESEHATAN MAHARDIKA, 4(1).

23. Mafticha, E. (2015) "HUBUNGAN URUTAN KELAHIRAN DAN KEMATIAN NEONATAL DI INDONESIA(ANALISIS DATA SURVEI DEMOGRAFI DAN KESEHATAN INDONESIA TAHUN 2012)," "Мепијu Masyarakat Madani dan Lestari, 5.

24. Makmun. (2018) "Kesehatan Remaja Produktif"
Jakarta : Reprocomp

25. Meihartati, T. (2017) "HUBUNGAN KEHAMILAN USIA DINI DENGAN KEJADIAN PERSALINAN PREMATUR DI RUANG BERSALIN RUMAH SAKIT IBU DAN ANAK PARADISE TAHUN 2015," 2(1), hal. 12-21.

26. Muntamah, A. L., Latifiani, D. dan Arifin, R. (2019) "Pernikahan Dini Di Indonesia: Faktor Dan Peran Pemerintah (Perspektif Penegakan Dan Perlindungan Hukum Bagi Anak)," Widya Yuridika, 2(1), hal. 1. doi: 10.31328/wy.v2i1.823.

27. Mutmainah, F., \& Sulistyoningtyas, S. (2017). Hubungan Pengetahuan dengan Sikap Remaja terhadap Pernikahan DIni di SMA Negeri 1 Gamping Sleman (Doctoral dissertation, Universitas' Aisyiyah Yogyakarta).

28. Notoatmodjo, Soekidjo (2010) "Ilmu Kesehatan Masyarakat dan Seni” Jakarta : Rineka Cipta

29. ------------------ (2015) "Perilaku

Kesehatan. Jakarta" : Rineka Cipta

30. Nursalam. (2016) "Persepsi Usia Pernikahan Idea”l. Jakarta: Rineka Cipta.

31. Pratiwi, W. R., Hamdiyah, H. dan Asnuddin, A. (2020) "Deteksi Dini Masalah Kesehatan Reproduksi Melalui Pos Kesehatan Remaja," JIP EMAS: Jurnal Inovasi Hasil Pengabdian Masyarakat, 3(1), hal. 87. doi: 10.33474/jipemas.v3i1.5035.

32. Purnamawati Ani, P. R. (2012) "Gambaran Penyebab Pernikahan Usia Dini Pada Remaja di Kecamatan Ciwaru Kabupaten Kuningan," Jurnal Ilmu Kesehatan Bhakti Husada: Health Sciences Journal, (Vol 1 No 1 (2012): Jurnal Ilmu Kesehatan Bhakti Husada), hal. 6-10. Tersedia pada:

https://ejournal.stikku.ac.id/index.php/stikku/arti cle/view/12.

33. Restiani, R. dan Arif, A. (2013) "Hubungan Umur Dan Paritas Dengan Kejadian Berat Bayi Lahir Rendah (BBLR) DI RSUD SOLOK," E-Jurnal Obstretika, 1(1), hal. 22-37.

34. Safari, F. R. N. (2017) "Faktor-Faktor yang Berhubungan dengan Kejadian Ketuban Pecah Dini di Rumah Sakit Umum H. Abdul Manan Simatupang Tahun 2016," Wahana Inovasi, Vol 6(No (2)), hal. 6.

35. Sujianti (2018) "Hubungan usia ibu dengan kejadian Bayi Berat Lahir Rendah (BBLR) di RSUD Cilacap," Kesehatan Al-Irsyad, XI(1), hal. 62-67.

36. Tukiman, Y. H. dan (2006) "DAMPAK 
PERNIKAHAN DINI TERHADAP

KESEHATAN ALAT REPRODUKSI

WANITA," hal. 36-43.

37. Wilda, Y. dan Suparji (2020) "Dampak Faktor Usia dan Paritas Terhadap Prevalensi Ketuban Pecah Dini Ibu pada Masa Bersalin," TunasTunas Riset Kesehatan, 10, hal. 67-71.

38. Wiradharma, W., I Md, K. dan I Wyn, D. A. (2016) "Risiko Asfiksia pada Ketuban Pecah Dini di RSUP Sanglah," Sari Pediatri, 14(5), hal. 316. doi: 10.14238/sp14.5.2013.316-9.

39. Yustati, N. (2018) "HUBUNGAN USIA PERTAMA KALI MENIKAH DENGAN KEJADIAN KANKER SERVIKS PADA IBU YANG MELAKUKAN PAP SMEAR DI RSUD WONOSARI."

40. Zoni Saeful Mubarok, A., Setiyono, A. dan Dienul Haq Ratnasari, R. (2019) "PENGARUH PERNIKAHAN DINI TERHADAP KEJADIAN BERAT BAYI LAHIR RENDAH DI KECAMATAN BUNGURSARI KOTA TASIKMALAYA," The Hokuriku Crop Science, 3, hal. 1-3. doi: 10.19016/jcshokuriku.3.0_1 